Collier, David A. "FISCH, flexible joints an panic: are anxiety disorders really expressions of instability in the human genome?"

British Journal of Psychiatry, 181, 457-59, 2002.

Resenhado por: Joyce M. Gonçalves Freire

\title{
O implacável gene causador da ansiedade e do pânico
}

A pesquisa genética psiquiátrica, de par em par com o seqüenciamento do genoma humano, não tem medido esforços para explicar as doenças mentais pelo método exclusivo do material genético. De uma transcrição genética não muito bem feita no momento em que as duas células originárias se unem, ou por meio do que herdamos de nossos pais, estaria traçado nosso destino errante de ser portador de uma doença mental. Antes mesmo de termos a identidade do que viríamos a ser, uma identidade genética delimitaria o espaço daquela que se nomeará como si mesmo.

Nesse artigo, publicado no editorial do British Journal of Psychiatry, o autor traz à cena as mais recentes descobertas genéticas, que resultam no isolamento de novos genes, os quais seriam os causadores de inúmeras doenças, dentre elas as mentais. Segundo Collier, a pesquisa genética levou algumas décadas para identificar o locus genético da esquizofrenia e, em relação aos distúrbios de ansiedade, tema do artigo, ela é ainda incipiente.

Seriam alguns distúrbios psiquiátricos realmente uma expressão das "genomic disorders", e se a resposta for afirmativa, pergunta o autor, como isto mudará nossa percepção de doença mental?

Collier aponta que pesquisas recentes sobre distúrbios de pânico, fobia social, agorafobia e outras formas de ansiedade 
poderiam ter suas causas encontradas inteiramente dentro do genoma humano (Gratacos et al, 2001). Nesta constelação de doenças psiquiátricas, foi encontrada, no cromossomo 15, uma bizarra torção a partir da qual haveria três cópias de 60 genes na maioria das células, onde o usual seriam duas. A forma pela qual a pesquisa apontou a relação dessa cópia triplicada no cromossomo 15 com os distúrbios de pânico, a conduziu a um labirinto no qual um dos caminhos indicava uma co-morbidade com a síndrome das articulações lassas e mais frágeis, que resultam em uma hipermobilidade. Considerou-se então que essa alteração no cromossomo 15 poderia ser relevante para as doenças nas quais a ansiedade estava presente e, utilizando-se de uma detalhada técnica denominada fluorescence in situ hybridisation (FISH), atribui-se àquela alteração (nomeada DUP25) a causa dos distúrbios de pânico na esmagadora maioria dos casos.

No entanto, a seqüência dessa pesquisa mostrou que duplicações de genes nas células ocorrem de formas diversas e estão altamente presentes nas células cerebrais. Os autores da pesquisa mostram que as alterações da região DUP25 do cromossomo 15 são diversas das de outros cromossomos e consideram que em alguns indivíduos toda a região torna-se altamente instável e propensa à recombinação. Apesar das muitas incertezas, eles observam que é provável que muitos genes dessa região estejam envolvidos no fenótipo causador da doença do pânico e da ansiedade em geral.

No próprio artigo, o autor faz uma breve referência às razões pelas quais a DUP25 é tão comum na população em geral: na evolução da espécie humana, a reduplicação na região 25 do cromossomo 15 foi selecionada por prover 0 sujeito (o espécime?) com respostas de medo e defesa a ameaças externas (sabese disto antes dessas descobertas genéticas). Alguns pesquisadores citados pelo autor (Lelliott et al, 1989) consideram mesmo que o primeiro ataque de pânico geralmente se dá em lugares públicos em razão desse fator evolucionário.

Não é paradoxal que o mesmo DUP25 estando envolvido nos ataques de pânico e ansiedade, possa ser também uma variante comum na espécie e lhe tenha conferido vantagens de sobrevivência? Contudo, Collier considera que se estas pesquisas forem confirmadas, testes genéticos, em breve, poderão tornar-se avaliações para desordens do pânico com os resultados fenotípicos correspondentes. Isto, de acordo com o autor, traria vantagens não só para o diagnóstico, mas, em especial, Collier supõe que "os testes genéticos poderiam também fazer os pacientes sentirem-se melhor em relação à sua condição, uma vez que eles saberiam que isto tem uma origem biológica” (p. 458). Além dessas vantagens, há a perspectiva de melhorar o tratamento dos distúrbios de pânico se alguns receptores envolvidos na reduplicação dessa região do cromossomo 15 puderem ser atingidos e amortecidos. Até que a neurogenética encontre respostas mais exatas sobre a instabilidade de alguns genes causadores dos 
distúrbios de pânico (e de outras doenças mentais) o autor considera que o melhor tratamento para as doenças genômicas ainda é a estratégia cognitiva.

Se esses argumentos do autor estiverem corretos com relação aos distúrbios de pânico, serão válidos também para outras tantas doenças mentais? Para o autor, a resposta é positiva. Contudo, há algo que a ideologia que se veicula a partir da pesquisa genética não contempla. Tanto quanto ela nos diz, seu pânico é efeito de uma torção no cromossomo 15 - e isto supostamente nos tranqüilizaria, pois estaríamos isentos de qualquer responsabilidade pelo mal que sentimos - também pode-se dizer, se assim o desejarmos, se temos uma transcrição gaguejante, como escreve o filósofo Slavoj Zizek, de citosina-adenina-guanina que nos mostrará, com precisão, quando teremos as primeiras manifestações de loucura, caso sejamos portadores da doença de Huntington. Sábios, os descobridores desses genes preferiram a ignorância de suas próprias identidades genéticas. Talvez para não ficarem loucos antes da data fatal - neste caso, pelas reações subjetivas frente ao implacável gene.

Diante da incontornável pesquisa genética que expõe de forma tão arrebatadora a massa orgânica com a qual fomos feitos, não há como discordar do filósofo citado ao escrever que somos "forçados a transformar e reinventar as próprias noções de liberdade, de autonomia e responsabilidade ética”. ${ }^{1}$ Se a ficção científica criada por nós, humanos, tornou-se real demais, teremos então que reinventar a ilusão, a fantasia, a ficção de nós mesmos. A psicanálise pode nos ajudar?

1. Zizek, S. A falha da bio-ética. Publicado no caderno "Mais!” Reengenharia Genética, Folha de S. Paulo, 22 de junho de 2003, p. 5. 